\title{
COVID-19, piel y estrés
}

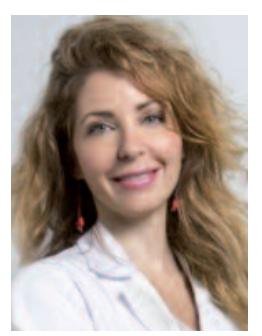

Elena González-Guerra Médico adjunto del Servicio de Dermatología. Hospital Universitario Clínico San Carlos. Madrid. Profesora asociada de Dermatología Médico-Quirúrgica y Venereología (Ciencias de la Salud). Departamento de Medicina. Universidad Complutense de Madrid. Directora del Máster en Dermofarmacia y Formulación Cosmética. Universidad Internacional de la Rioja (UNIR).

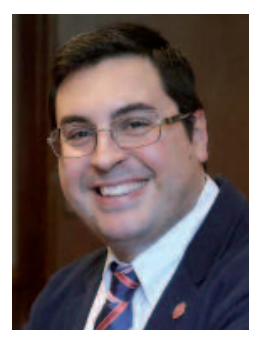

Víctor Vidal Lacosta Profesor del Área Biomédica. Inspector médico INSS-especialista en Medicina del Trabajo. Madrid.

\section{COVID-19}

La enfermedad por coronavirus de 2019 o COVID-19 (por el acrónimo en inglés de: coronavirus disease-2019) es el nombre de la enfermedad que ha asolado el mundo en los últimos meses. Su presencia ha supuesto la aparición de una situación absolutamente nueva para todos los humanos. Desde el propio virus hasta la repercusión social, económica y emocional que ha producido y todavía produce todo es novedoso. El escenario más parecido al actual fue el que se originó con la gripe de 1918, en el que murieron, según algunas referencias, cerca de 40 millones de personas. Pero eran otros tiempos. Y otro virus.

Sabemos que taxonómicamente el SARS-CoV-2 es un coronavirus, género del que ya tuvimos noticias en el año 2003, con el SARS-CoV, causante del síndrome respiratorio agudo grave o SARS (por las siglas en inglés de: severe acute respiratory syndrome), y en el año 2012 con el virus causante del síndrome respiratorio de Oriente Medio o MERS (por las siglas en inglés de: Middle East respiratory syndrome).

El SARS-CoV-2 se detecta como nueva infección en el mundo en noviembre de 2019, y el 13 de marzo de 2020, la Organización Mundial de la Salud declara el estado de pandemia. Su extensión y contagiosidad es rapidísima.

Desde entonces, hemos aprendido que todavía sabemos muy poco sobre la enfermedad. Aún así, hemos ido incorporando - y todavía lo hacemos día a día- nuevos conocimientos y nuevas controversias que van iluminando el camino del éxito. Por ejemplo, sabemos que, en los casos graves, se produce una inflamación -endotelitis, desregulación inmunitaria primaria y secundaria- que descarga una tormenta de citocinas nefasta. Son miles y miles —difícil y triste aventurar un número- las personas que han fallecido.

\section{PIEL}

Saber si la piel está implicada en este cuadro sistémico con unas manifestaciones propias ha sido uno de los temas discutidos por los dermatólogos con mayor eficiencia y unidad. La reciente publicación española ${ }^{1}$ ha puesto de manifiesto cinco patrones clínicos: 1) Acral, similar a la perniosis. 2) Vesiculoso, que recuerda a la varicela. 3) Urticariforme. 4) Maculo papuloso, generalizado. 5) Livedoide, con necrosis. Cada uno de estos patrones, que seguramente habrá que perfilar con más datos, implica una ayuda diagnóstica y una sugerencia pronóstica interesante. Sin embargo, hoy por hoy, carecemos de vacuna y de tratamiento eficaz y seguro. Solo podemos intentar prevenir el contagio. Para ello, además de las medidas de prevención genéricas individuales -mascarilla, lavado de manos, desinfección de enseres, distanciamien- 
to físico-, los gobiernos de diferentes países han decretado órdenes de confinamiento. Esto es, mantenerse aislado en el domicilio y no desplazarse, salvo en situaciones excepcionales.

Este contexto ha traído también como consecuencia que dermatosis ya existentes como el acné hayan dejado de pasar revisiones y tratarse convenientemente, empeorando; que pacientes con lesiones malignas como los carcinomas espinocelulares no hayan acudido a sus dermatólogos y no hayan sido diagnosticados prontamente, agravándose su pronóstico; que el uso de mascarillas o líquidos antisépticos haya originado foliculitis o eccemas; y un largo etcétera.

Pero junto a estos hechos clínicos, han aparecido trastornos emocionales, causados por el estrés tanto de la propia enfermedad como del confinamiento.

\section{ESTRÉS}

El estrés es la respuesta inadecuada del organismo ante situaciones de peligro agudas o crónicas, por agotamiento de los mecanismos adaptativos. La COVID-19 suma los ingredientes perfectos para que aparezca un estrés crónico, tanto por la propia enfermedad como por el confinamiento, aumentando los niveles de cortisol, adrenalina, noradrenalina, ACTH (hormona adrenocorticotropa), MSH (hormona estimulante de melanocitos) y prolactina. Aunque los sistemas más afectados son el cardiovascular, el neurológico y el endocrino, todos los demás sufren sus consecuencias. Y la piel no se libra de sus efectos: modifica el sistema inmunitario y activa vías de inflamación. Estas hormonas en la piel, a través de comunicación neuronal (células de Merkel y fibras neurocutáneas), producen una serie de neuromediadores y neuropéptidos que llegan a receptores de las células epidérmicas, dérmicas (mastocitos, células endoteliales, linfocitos) y de los anejos (sebocitos), engendrándose otras citocinas como la histamina, proteasas, quimiocinas, etc.
De esta forma, empeoran enfermedades cutáneas como la psoriasis, la dermatitis seborreica, la dermatitis atópica, el acné, etc. Surgen enfermedades propias de la inmunosupresión en la que colabora el estrés, como la recidiva de herpes simple o el brote de herpes zóster. O aparece la caída de pelo por paso rápido de la fase anágena a la telógena, esto es, el efluvio telógeno. Se acelera por la oxidación inflamatoria el envejecimiento cutáneo. Las fobias, los trastornos obsesivoscompulsivos, las autoagresiones, los delirios (tricotilomanía, onicofagia, excoriaciones neuróticas, delirios de parasitación, alcoholismo, drogadicción, etc.) resurgen si ya existían, o se presentan de forma novedosa.

Todas estas circunstancias colaboran deletéreamente en más estrés, retroalimentando la ansiedad y favoreciendo la depresión, la estigmatización, el miedo y la impotencia, que, de nuevo, repercuten en la piel.

\section{¿QUÉ HACER?}

La base de cualquier actuación frente a la COVID19 está en la información documentada y fiable. Es necesario acudir a los sistemas sanitarios que se vayan regulando y reinventando, como la teledermatología, prestando atención al consejo del dermatólogo.

Desde un punto de vista individual, utilizar todos los medios de prevención con responsabilidad es la principal herramienta para disminuir la ansiedad. La reflexión, la meditación, las técnicas de respiración, el ejercicio físico apropiado y la alimentación sana complementarán las medidas beneficiosas.

Y mantener la fe, la esperanza y la caridad.

\section{BIBLIOGRAFÍA}

1. Galván Casas $C$, Català $A$, Carretero Hernández G, Rodríguez-Jiménez P, Fernández-Nieto $D$, Rodríguez-Villa Lario A, et al. Classification of the cutaneous manifestations of COVID-19: a rapid prospective nationwide consensus study in Spain with 375 cases. Br J Dermatol. 2020;183(1):71-7. 